\begin{tabular}{lr}
\hline PRACE NAUKOWE UNIWERSYTETU EKONOMICZNEGO WE WROCLAWIU \\
RESEARCH PAPERS OF WROCLAW UNIVERSITY OF ECONOMICS & nr 485・2017 \\
\hline Relacje fiskalne państwo-samorząd terytorialny & ISSN 1899-3192 \\
& e-ISSN 2392-0041
\end{tabular}

\title{
Marzena Piszczek
}

Uniwersytet Ekonomiczny w Krakowie

e-mail: marzena.piszczek@gmail.com

\section{WIELOLETNIE PLANOWANIE FINANSOWE W SAMORZĄDZIE}

\section{LONG-TERM FINANCIAL PLANNING IN SELF-GOVERNANCE}

DOI: $10.15611 /$ pn.2017.485.29

JEL Classification: H72, H74, H79

\begin{abstract}
Streszczenie: Planowanie jako podstawowa funkcja procesu zarządzania stopniowo staje się jednym z podstawowych zakresów działania jednostek samorządu terytorialnego. Szczególnego znaczenia nabiera zarządzanie finansami w dłuższej perspektywie czasowej. Świadome podejmowanie decyzji o liczbie i zakresie zadań, przede wszystkim inwestycyjnych, następnie ich realizacja, wymaga zapewnienia odpowiednich środków finansowych. Narzędziem, które to umożliwia, jest wieloletni plan finansowy. Celem artykułu jest przedstawienie czynników determinujących efektywne wieloletnie planowanie finansowe w jednostkach samorządu terytorialnego, które może przyczynić się do lepszego wykorzystania środków publicznych.
\end{abstract}

Słowa kluczowe: wieloletnie planowanie finansowe, zarządzanie finansami.

Summary: Planning as a basic function of the management process is gradually becoming one of the main scopes of action of local government. Special importance of the financial management is the long term planning. Informed decision making about the number and scope of the tasks, specially investment tasks, and their execution, require providing adequate financial sources. A tool that makes it possible is a multiannual financial plan. The aim of the article is to present the factors determining affective long-term financial planning in local government, which can contribute to the better use of public funds.

Keywords: long-term financial planning, finance management.

\section{Wstęp}

Jednostki samorządu terytorialnego (JST) coraz częściej podejmują działania zarządcze ukierunkowujące działalność całej organizacji tak, aby dalekosiężne cele były realizowane jak najlepiej i najpewniej przy ekonomicznym wykorzystaniu dostępnych środków. To wymaga podejścia zintegrowanego do procesu zarządzania 
JST, który wymaga od zarządu JST przygotowania dokumentów wyznaczających najważniejsze cele wspólnoty, a następnie takiego zorganizowania pracy przy ich realizacji, aby do maksimum zostały wykorzystane efekty współdziałania wszystkich jednostek. Pozwala to na pełne wykorzystanie będących w dyspozycji JST możliwości, co w rezultacie pozwoli na podniesienie skuteczności działania, eliminację wydatków na działania niepotrzebne (marnotrawstwo), wybór najefektywniejszego sposobu działania (por. [Pakoński (red.) 2000, s. 10]).

Planowanie jako podstawowa funkcja procesu zarządzania stopniowo staje się jednym z podstawowych zakresów aktywności w procesie zarządzania w JST. Polega na projektowaniu pożądanego obrazu przyszłości oraz wskazania metod i dróg jego najefektywniejszego osiągnięcia. Jest to proces ciągłego zadawania pytań dotyczących przewidywanego stanu danej organizacji, otoczenia czy gospodarki w przyszłości. Zgodnie z cyklem procesu zarządzania planowanie jest elementem początkującym cały mechanizm zarządczy (por. [Dylewski 2007, s. 60]).

Celem artykułu jest przedstawienie czynników determinujących efektywne wieloletnie planowanie finansowe w jednostkach samorządu terytorialnego, które może przyczynić się do lepszego wykorzystania środków publicznych.

Zastosowaną metodą badawczą jest krytyczna analiza literatury oraz aktów normatywnych z zakresu sektora finansów publicznych, a także metoda obserwacji.

Zasadnicza teza opracowania zawiera się w stwierdzeniu, iż wieloletnie planowanie finansowe może przyczynić się do lepszego wykorzystania środków publicznych pod warunkiem, że zostanie ono prawidłowo zaimplementowane oraz że zostaną usunięte bariery ograniczające dzisiaj praktyczne wykorzystanie tego narzędzia.

Rosnąca rola planowania finansowego i zarządzania finansami JST związana jest z obiektywnie występującymi czynnikami: demograficznymi, ekonomicznymi, społecznymi oraz globalizacją, które mają negatywny wpływ na funkcjonowanie wielu JST, szczególnie ich kondycję finansową oraz możliwości rozwojowe, a które podlegają ciągłym zmianom (por. [Surówka 2016; Szewczuk 2016; Jastrzębska 2016; Czekaj 2015]). Dodatkowym argumentem za przybliżeniem tego tematu jest wprowadzony przepisami obowiązek sporządzania wieloletniej prognozy finansowej (WPF) ${ }^{1}$ przez JST wraz z nowymi zasadami zarządzania długiem ([Ustawa $z$ dnia 27.08.2009] dalej ufp).

W artykule przedstawiono też wzajemne zależności i powiązania występujące pomiędzy procesami planowania wieloletniego, planowania inwestycyjnego oraz budżetem JST.

${ }^{1}$ Do praktyki planowania samorządowego jako obowiązująca od 2011 roku została wprowadzona art. 226 ustawy o finansach publicznych (Dz.U. z dnia 27.08.2009, Dz.U. z 2013, poz. 885 ze zm.). 


\section{Wieloletnie planowanie finansowe}

Wieloletnie planowanie wiąże się z perspektywicznym myśleniem i podejmowaniem decyzji skutkujących w długim terminie. Wieloletnie planowanie finansowanie jest procesem określania możliwości finansowych JST w dłuższym okresie. Pozwala wariantowo szacować przyszłe dochody i wydatki JST oraz poziomy nadwyżki lub deficytu, tj. czynniki, które decydują o skali kredytowania i kosztach obsługi zobowiązań zaciągniętych oraz przewidzianych do zaciągnięcia. Wieloletni plan finansowy (WPF) powstaje w wyniku wieloletniego planowania finansowego i analizy różnych wariantów finansowania zadań, które służą do realizacji celów zdefiniowanych w strategii rozwoju JST. WPF jest narzędziem racjonalnego gospodarowania środkami publicznymi, a jego integralną częścią jest zarządzanie długiem. K. Cichocki [2001] definiuje cechy charakterystyczne WPF. Są to:

- wieloletnia perspektywa w planach zadań inwestycyjnych i operacyjnych,

- kompletność planów realizacyjnych budżetu i wszystkich jednostek świadczących usługi dla mieszkańców, niezależnie od ich formy organizacyjnej,

- efektywność zarządzania; naczelną zasadą przy sporządzaniu WPF jest efektywne planowanie i zarządzanie środkami własnymi i długiem,

- uczestnictwo mieszkańców w zarządzaniu JST, realizacja zadań oraz ich cele są przedmiotem dialogu i oceny mieszkańców.

Autor wskazuje też na trzy filary dobrego WPF, do których zalicza pełną, klarowną wiarygodną sprawozdawczość finansową, wiarygodne prognozy budżetu obejmującego dochody, wydatki, a także dług i jego obsługę, wreszcie pozyskanie najtańszego pieniądza na finansowanie wieloletnich zadań infrastrukturalnych [Cichocki 2001, s. 10-11]. W literaturze podkreśla się, że WPF powinna być ważnym narzędziem poprawy alokacji środków budżetowych i integralnym elementem strategii rozwoju JST.

Wieloletnie planowanie finansowe łączy planowanie strategiczne i roczne przygotowanie budżetu. Uważane jest za relatywnie nowy model aktywnego wpływania na przyszłe wydarzenia. Polega na identyfikacji problemów długoplanowych i kierowaniu funduszy oraz zasobów do ich rozwiązywania w okresie 5-10 lat. Model ten koncentruje się na długofalowych skutkach decyzji.

Wieloletnie planowanie finansowe może być utożsamiane z planowaniem strategicznym $\mathrm{w}$ przedsiębiorstwach i innych organizacjach i powinno być integralną częścią zarządzania jednostką publiczna, w związku z czym musi uwzględniać m.in. ograniczenia finansowe, inne ograniczenia zasobowe, sprzeczne interesy różnych grup wpływających na funkcjonowanie jednostki, niedostatek informacji na etapie przygotowania planów czy przewidywane zmiany w otoczeniu. Musi też łączyć w sposób spójny inne dokumenty planistyczne przygotowane przez JST (wewnętrzna spójność i zgodność) [Wyszkowska, Wyszkowski 2016, s. 14-15].

Wieloletnie planowanie finansowe jest jedną z wielu uzupełniających się metod w ramach zintegrowanego zarządzania JST i poza samym WPF obejmuje metodo- 
logię wieloletniego planowania inwestycji (WPI), budżetowanie zadaniowe 2 , budowanie strategii JST oraz jej polityk sektorowych. WPF jest niejako wspólnym mianownikiem wszystkich wymienionych, określa możliwości finansowe i wyznacza ich perspektywę (por. rys. 1).

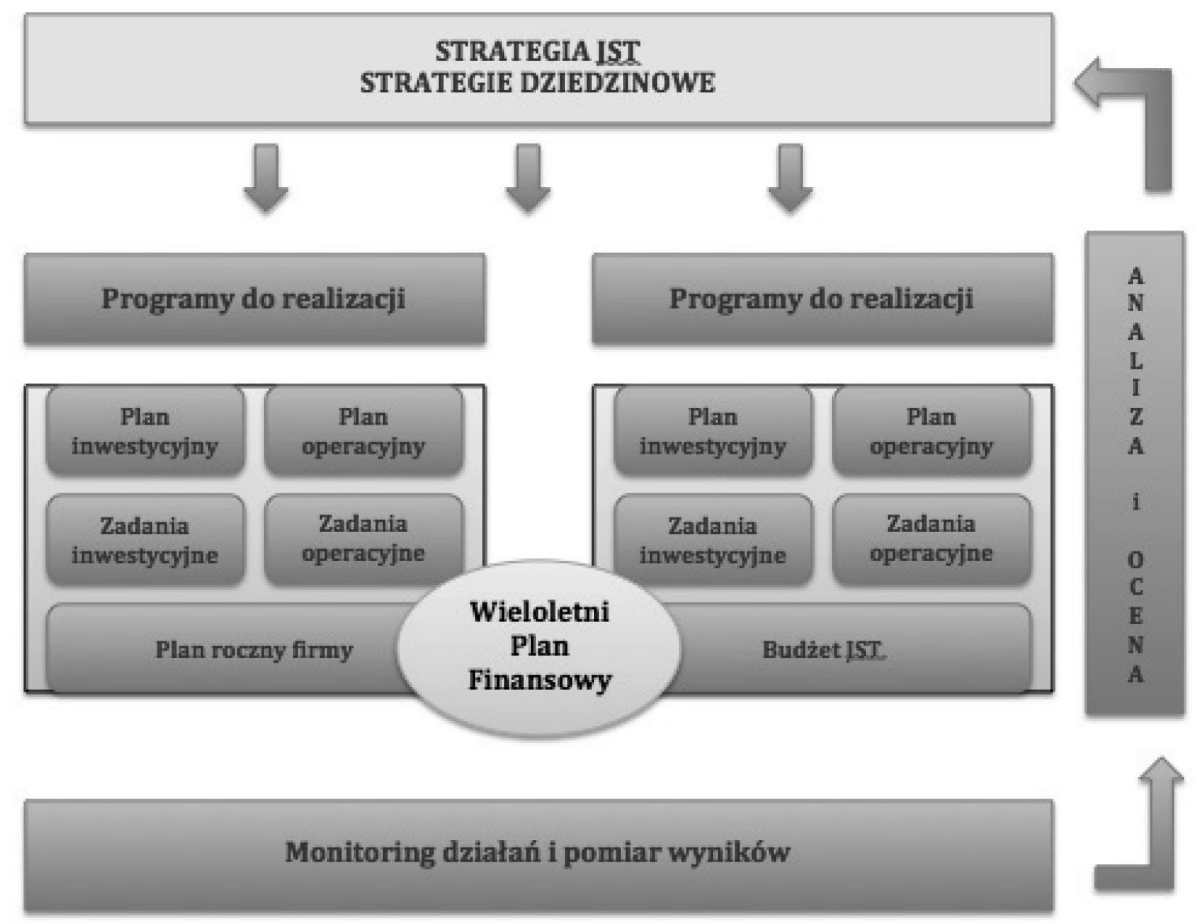

Rys. 1. Wieloletni plan finansowy na tle zintegrowanego zarządzania JST

Źródło: opracowanie własne na podstawie [Pakoński (red.) 2000 s. 15].

Pomiędzy WPF a pozostałymi wymienionymi technikami występują pewne zależności. Aby zapewnić maksymalną efektywność działań, warto je rozpoznać i wykorzystać przy poodejmowaniu decyzji. Szczególnej analizie warto poddać związki pomiędzy WPF a planowaniem rocznym w układzie zadań, które cechują: wysoka precyzyjność i wiarygodność, wynikające z metodologii budżetowania zadaniowego opartego na koszcie jednostkowym usług, oraz inne parametry, jak zakres rzeczowy zadania wraz z miernikami ${ }^{3}$.

${ }^{2}$ Badania przeprowadzone przez Ministerstwo Finansów w 2013 r. potwierdziły, iż polskie JST rzadko korzystają z tej metodologii. Szkoda, gdyż prawidłowo zastosowana zapewnia wysoki poziom precyzji planowania zadań bieżących.

${ }^{3}$ Szerzej na temat budżetowania zadaniowego w: [Filas, Piszczek, Stobnicka 1999; Filas, Piszczek 1999]. 
Wieloletni plan finansowy zapewnia przygotowanie dokładnych prognoz dochodów i wydatków, a tym samym dokładne wyliczenie w kolejnych latach prognozy takich wartości wydatków inwestycyjnych i bieżących oraz kwoty nowego długu, które spełniają warunki efektywnego zarządzania finansami, a przede wszystkim warunek zachowania płynności finansowej budżetu. W szczególności odnosi się to zasady wynikającej z art. 242 ufp, dotyczącej zrównoważonych wydatków bieżących budżetu oraz limitowania całkowitych wydatków obsługi zadłużenia JST wynikających z art. 243 ufp.

Zakres WPF został określony przez art. 226 ufp. Zgodnie z jego zapisami WPF powinna być realistyczna i określać dla każdego roku objętego prognoza co najmniej:

1) dochody bieżące oraz wydatki bieżące budżetu JST, w tym na obsługę długu, gwarancje i poręczenia,

2) dochody majątkowe, w tym dochody ze sprzedaży majątku, oraz wydatki majątkowe budżetu JST,

3) wynik budżetu JST,

4) przeznaczenie nadwyżki albo sposób sfinansowania deficytu,

5) przychody i rozchody budżetu JST, z uwzględnieniem długu zaciągniętego oraz planowanego do zaciągnięcia,

6) kwotę długu JST oraz sposób sfinansowania jego spłaty,

7) kwoty wydatków bieżących i majątkowych wynikających z limitów wydatków na planowane i realizowane przedsięwzięcia, przez które należy rozumieć wieloletnie programy, projekty lub zadania, $w$ tym związane z programami finansowanymi z udziałem środków, o których mowa w art. 5 ust. 1 pkt 2 i 3 ufp oraz umowami o partnerstwie publiczno-prywatnym.

W załączniku do uchwały w sprawie wieloletniej prognozy finansowej określa się odrębnie dla każdego przedsięwzięcia:

1) nazwę i cel,

2) jednostkę organizacyjna odpowiedzialna za realizacje lub koordynującą wykonywanie przedsięwzięcia,

3) okres realizacji i łączne nakłady finansowe,

4) limity wydatków w poszczególnych latach,

5) limit zobowiązań.

Do wieloletniej prognozy finansowej dołącza się objaśnienia przyjętych wartości, w których mogą być zawarte także informacje uszczegóławiające dane.

Z kolei art. 227 ufp mówi, iż WPF obejmuje okres roku budżetowego oraz co najmniej trzech kolejnych lat budżetowych. Natomiast prognozę kwoty długu, stanowiąca część WPF, sporządza się na okres, na który zaciągnięto oraz planuje się zaciągnąć zobowiązania. Zapis ten powoduje realne wydłużenie czasu, na jaki WPF są sporządzane nawet do kilkudziesięciu lat.

Jak wspomniano, WPF umożliwia także zaplanowanie finansowania WPI oraz dopasowanie finansowania do płynności budżetu i bezpiecznego dla budżetu poziomu długu. 
Proces zarządzania długiem w JST polega na określaniu zdolności JST do jego zaciągania i możliwości spłaty, określenia bezpiecznego poziomu zadłużenia, jak i najefektywniejszego i rozważnego wykorzystania źródeł rynku finansowego, określenia ryzyka związanego z wybraną metodą finansowania i efektywnym monitorowaniem terminów spłat wszystkich rat i odsetek. Proces ten wymaga też od JST poprawy zarządzania gotówką, przewidzenia luk w jej przepływie i wiąże się z maksymalizowaniem przychodów z odsetek od kapitału.

Wieloletnie planowanie finansowe, którego integralną częścią jest prognoza długu i jego spłaty, jest obok budżetu najważniejszym dokumentem planowania finansowego. Prognoza długu należy do tych elementów WPF, które dają wyobrażenie o jakości wieloletniego planowania finansowego w jednostce samorządowej i powinna obejmować wszystkie formy długu. W literaturze przedmiotu można znaleźć zalecenia co do minimalnego okresu, na jaki WPF powinna być sporządzana (nie krótszy niż 7 lat), gdyż - w przeciwnym razie - nie można mówić o efektywnym planowaniu wieloletnim, w szczególności nie jest możliwe wtedy planowanie przyszłych zadań inwestycyjnych (por. [Cichocki 2013]).

W ramach prowadzonej polityki zadłużenia jednym z najważniejszych zadań jest wyznaczenie optymalnego poziomu zadłużenia w sposób jak najbardziej odpowiedzialny i rzetelny. B. Nawrocki [2016, s. 27] definiuje optymalny poziom zadłużenia jako taki, które będzie do spłaty, zanim pojawi się konieczność odtworzenia majątku trwałego JST, pozwalającego na utrzymanie we wszystkich latach prognozy odpowiedniej płynności budżetowej oraz gwarantującego zachowanie zdolności kredytowej JST bez groźby wpadnięcia $\mathrm{w}$ pułapkę zadłużeniową. Tak określone zadłużenie pozwoli też ostatecznie na wyznaczenie skali możliwych do zrealizowania inwestycji (podobnie [Jastrzębska 2016]). Określenie optymalnego zadłużenia na podstawie funkcjonujących zasad wieloletniego planowania nabiera szczególnego znaczenia w sytuacji możliwych wyłączeń z limitu zadłużenia ( $w$ ramach obowiązującego systemu ograniczania zadłużenia samorządowego) oraz instrumentów pozabilansowego finansowania inwestycji, które również pozostają poza systemem limitowym. Wiarygodność oceny możliwości realizacji WPF, w tym określenia optymalnego poziomu zadłużenia zależy w ogromnym stopniu od poprawnie oszacowanych dochodów i wydatków bieżących, zwłaszcza ze sprzedaży majątku, i wpływa na poprawność formułowanych wniosków oraz skuteczność podejmowanych przez JST decyzji rozwojowych.

Prognozowanie dochodów i wydatków, oszacowanie przyszłego potencjału JST nie jest zadaniem łatwym. Czynniki, które ograniczają możliwość trafnego przewidywania przyszłych dochodów czy wydatków, wynikają z niepewności związanej z przyszłą sytuacją zarówno makroekonomiczną, jak i lokalną, a także z niedoskonałości zarządzania JST, brakami w zdefiniowaniu określonych polityk, np. polityki zarządzania długiem, mieniem komunalnym, czy brakiem polityk sektorowych dla usług. Dlatego pomocne w opracowaniu WPF jest wcześniejsze przygotowanie wspomnianych polityk sektorowych czy określenie polityki wykorzystania lub sprzedaży mienia. 
W odniesieniu do dochodów podstawowy podział, jaki stosuje się przy ich planowaniu, to podział na dochody bieżące oraz majątkowe, a także wyróżnia się dochody własne czy też pozyskane z różnego rodzaju dotacji ze źródeł pozabudżetowych, które służą realizacji zadań inwestycyjnych. Uwzględnienie tych ostatnich, ze względu na niepewność ich pozyskania, warto zamieścić w wariancie alternatywnym (optymistycznym) WPF.

Aby opracowane prognozy dochodów były trafne, planujący musi dobrze rozpoznać i rozumieć system, który generuje dochody JST, mieć pełną diagnozę i zrozumienie czynników, które miały wpływ na ich wysokość, a także diagnozę procesów i zmian, jakie mogą mieć wpływ na przyszłe dochody JST. Należy więc wziąć pod uwagę nie tylko ich strukturę, ale też prawidłowości, które rządzą stroną dochodów, jakie można stwierdzić na podstawie danych historycznych. Przygotowanie dobrej prognozy opiera się na przeanalizowaniu zmian i trendów ogólnogospodarczych, które mogą mieć wpływ na sytuację danej JST, jak np. obniżenie dynamiki PKB, związane z nim spowolnienie rozwoju lokalnego, wzrost stopy bezrobocia, ujawnienie się innych problemów społecznych (np. zmiany demograficzne, migracja ludności, etc.), i ich wpływ chociażby na udział w takich kategoriach dochodowych, jak PIT czy CIT.

Przy konstruowaniu prognozy wydatków, podobnie jak przy prognozie dochodów, ważna jest analiza ich struktury, szczególnie z podziałem na wydatki bieżące i inwestycyjne. Pierwszym etapem w opracowaniu prognozy wydatków JST jest ich rozdział na wydatki bieżące i inwestycyjne. Te pierwsze obejmują wszystkie koszty związane z wykonywaniem zadań własnych i zleconych na takim poziomie, aby wypełnić podstawowe funkcje i zadania JST. Gdyby miały pojawić się jakiekolwiek trudności z finansowaniem zadań, to w pierwszej kolejności mają być zabezpieczone środki na wydatki związane $\mathrm{z}$ obowiązkowymi zadaniami zleconymi. Prognozując wydatki, należy wziąć pod uwagę m.in. zmienne w czasie zapotrzebowanie na usługi, krąg usługobiorców oraz zakres świadczeń, jakie będzie zobowiązana dostarczyć JST, szczególnie w sytuacji, gdyby to dostarczanie usług miało wiązać się z poniesieniem dodatkowych nakładów w związku z koniecznością zatrudnienia dodatkowych pracowników czy też rozbudową lub modernizacją infrastruktury.

Przyjęcie dobrych założeń do projekcji wydatków bieżących wymaga dobrej znajomości struktury poszczególnych pozycji budżetowych, a także znajomości realizowanych zadań. Narzędziem, które doskonale nadaje się do tego celu, jest budżet zadaniowy. Jego konstrukcja pozwala na zmniejszenie wydatków bieżących przy zachowaniu poziomu świadczenia usług. Warto też pamiętać, iż dla wielu dziedzin cechą charakterystyczną jest duży udział wydatków na wynagrodzenia w wydatkach bieżących, i wówczas tempo wzrostu wydatków bieżących zależy od tempa wzrostu wynagrodzeń. Dla niektórych dziedzin to, jak będą kształtowały się wydatki budżetowe, będzie zależeć od przyjętej polityki zarządzania JST, w szczególności przyjętych priorytetów. Jednak dla wielu dziedzin, poza powyższym zastrzeżeniem, będą to współczynniki zmian oraz prognozowane parametry makroekonomiczne, jak: 
tempo zmian PKB, stopa inflacji, przewidywane tempo wzrostu stóp procentowych, a także lokalne trendy historyczne czy wskaźniki korygujące.

Inną wyodrębnioną kategorią do zaprognozowania będą: kwoty obsługi długu czy koszty eksploatacji majątku trwałego. W ramach wydatków bieżących najczęściej dokonuje się podziału tych wydatków na rzeczowe, osobowe, remontowe oraz pozostałe wydatki bieżące.

Prognoza wydatków bieżących jest ściśle powiązana z prognozą dochodów oraz dodatkowo należy mieć na względzie zadania wynikające z WPI, gdyż to z nimi właśnie będą się wiązały określone wpływy do budżetu lub wydatki w związku z oddaniem inwestycji do eksploatacji. Rzeczywisty wynik finansowy JST na koniec roku budżetowego musi uwzględniać też, poza dochodami i wydatkami, przychody i rozchody. Chcąc uzyskać kwotę, jaka pozostanie w kasie na koniec roku budżetowego, należy wielkość nadwyżki operacyjnej pomniejszyć o koszty obsługi długu oraz wydatki inwestycyjne i spłatę należnych rat długu, a powiększyć o pozyskane środki pożyczkowe (z kredytu, obligacji), dochody majątkowe oraz przychody z prywatyzacji. Ponadto do powyższej kwoty należy dodać nadwyżkę budżetową z roku ubiegłego, oraz tzw. wolne środki na rachunku bieżącym z roku ubiegłego.

Metody prognozowania przychodów i rozchodów oraz wydatków inwestycyjnych są ściśle powiązane z wynikiem operacyjnym budżetu - nadwyżką operacyjną rozumianą jako różnica pomiędzy dochodami bieżącymi a wydatkami bieżącymi. Informuje ona, jaka wielkość budżetu w danym roku może być przeznaczona na finansowanie inwestycji bez obciążenia przyszłych budżetów kosztami obsługi długu. Wartość tej nadwyżki w relacji do dochodów stanowi podstawową miarę możliwości finansowania projektów inwestycyjnych.

To, w jakim stopniu WPF będzie stanowić instrument strategicznego zarządzania, zależy nie tylko od jego konstrukcji, ale też od tego, jaka metodologia zostanie zastosowana przy jego opracowaniu. J. Salachna [2015, s. 63] wskazuje, iż wieloletnie planowanie o charakterze strategicznym powinno obejmować co najmniej następujące etapy:

- analizę priorytetów, która powinna się skupiać na oczekiwaniach interesariuszy (wspólnoty samorządowej) oraz misji organizacji (głównych zadaniach danej JST),

- wybór optymalnej w danych warunkach i okresie strategii spośród dostępnych opcji postępowania,

- $\quad$ implementację strategii, która obejmuje zarówno planowanie zasobów koniecznych do realizacji obranej strategii, jak i określenie ewentualnych zmian struktury organizacyjnej czy systemów kontroli służących wykonaniu przyjętej strategii.

WPF może być narzędziem zarządzania pod warunkiem, że ma niezbędne cechy strategii oraz powstała w procesie uwzględniającym wyżej wymienione etapy. Analiza obowiązujących unormowań odnoszących się do WPF, w szczególności konstrukcja wskaźnika zadłużenia, liczne wyłączenia z kategorii długu, a także pozabilansowe instrumenty finansowania inwestycji czy wreszcie sam okres, na jaki jest sporządzany 
plan - sięgający czasem nawet kilkudziesięciu lat! - czyni dzisiaj z WPF niewiarygodne narzędzie prognostyczne (por. [Salachna 2015; Tarnowski 2015; Woźniak 2015]) i tym samy na tym etapie nie może być uznane za efektywnie wykorzystywane do zarządzania potencjałem JST. Niemniej jednak, jak podkreśla B. Filipiak [2016], ustawodawca stworzył nie tylko przesłankę planowania wieloletniego w Polsce, ale jeden z wielu instrumentów planistycznych o randze ustawowej do zarządzania samorządowym długiem publicznym oraz finansami samorządowymi.

W tabeli 1 została przedstawiona wieloletnia prognoza podstawowych kategorii finansowych: dochodów i wydatków, nadwyżki operacyjnej (rozumianej jako różnica pomiędzy dochodami bieżącymi a wydatkami bieżącymi budżetu) oraz planowanego zadłużenia dla wszystkich JST w latach 2014-2017, a także wykonanie tych kategorii za lata 2014-2016 wraz z ich dynamiką.

Na podstawie danych z tabeli 1 można stwierdzić, iż JST planują dodatni wynik budżetów, który w 2017 roku ma osiągnąć kwotę 5,9 mld zł. Podobnie jeśli chodzi o kwotę nadwyżki operacyjnej, dla tego samego roku została zaplanowana na kwotę ok. 17,6 mld. WPF wskazuje też, iż relatywnie do dochodów ogółem maleć będzie zadłużenie JST z 37,8\% w roku 2014 do 33,8\% w roku 2017, co w kwotach ogółem oznacza spadek z 75,04 mld w 2014 roku do kwoty 61,71 mld zł.

Powyższe dane stanowią oczywiście średnią dla wszystkich JST w Polsce. Sytuacja $\mathrm{w}$ poszczególnych JST może wyglądać zgoła odmiennie. Ponadto należy uwzględnić $\mathrm{w}$ analizie danych fakt, iż wielokrotnie była kwestionowana wiarygodność danych zawartych w WPF. Analiza porównawcza planu i wykonania poszczególnych kategorii WPF pozostawia wiele do życzenia i potwierdza znaczące odchylenia w stosunku do planu'.

Na podstawie danych z tabeli 1 można postawić tezę, iż dla wielu kategorii nietrafność planowania cechują nie kilkunastoprocentowe, lecz nawet kilkudziesięcioprocentowe odchylenia, zarówno w dół, jak i w górę. Poza kwotą dotacji na cele bieżące, w przypadku której wykonanie roku 2016 miało prawo wskazywać na znaczne odchylenia od planu (239,92\%), co wiązało się z wprowadzonym nowym programem rządowym, w zasadzie wszystkie pozostałe kategorie cechuje wysoka nietrafność planowania i wykonania budżetu. Wysokie odchylenia planu i wykonania obserwujemy w kategorii „dochody ogółem” (wskaźnik wykonanie - plan za rok 2016 wynosi 117,56\%), dla dochodów bieżących (117,96\%), podobnie dla wydatków ogółem czy wydatków bieżących, dla których wspomniany wskaźnik dla roku 2016 w obu przypadkach wynosi ok. 116\%. Niską jakość planowania daje się zaobserwować dla takich kategorii, jak: wydatki na obsługę długu (wskaźnik wykonanie - plan w roku 2015 wynosił 59,5\%, a w roku 2016 jeszcze mniej: 57,03\%), czy wydatki bieżące na wynagrodzenia (wskaźnik za rok 2016 wynosi 90,34\%). Chociaż samo zjawisko malejących kosztów obsługi zadłużenia czy spadku wynagrodzeń należy uznać za jak najbardziej pożądane, to jednak w kontekście przedstawianego

\footnotetext{
${ }^{4}$ Szerzej na ten temat w: [Piszczek 2016, s. 95-108].
} 
Tabela 1. Prognoza wybranych kategorii finansowych: dochodów i wydatków, nadwyżki operacyjnej oraz zadłużenia dla jednostek samorządu terytorialnego w latach 2014-2017 oraz wykonania wybranych kategorii finansowych dla jednostek samorządu terytorialnego w latach 2014-2016 wraz z ich dynamiką

\begin{tabular}{|c|c|c|c|c|c|c|c|c|c|c|}
\hline Ogółem JST & \multicolumn{4}{|c|}{ Plan WPF } & \multicolumn{3}{|c|}{ Wykonanie } & \multirow{2}{*}{\multicolumn{3}{|c|}{ Dynamika w \% }} \\
\hline \multirow{2}{*}{ Wyszczególnienie } & 2014 & 2015 & 2016 & 2017 & 2014 & 2015 & 2016 & & & \\
\hline & 1 & 2 & 3 & 4 & 5 & 6 & 7 & $5: 1$ & $6: 2$ & $7: 3$ \\
\hline 1. DOCHODY OGÓŁEM & 198,56 & 188,99 & 181,76 & 182,67 & 194,34 & 199,02 & 213,67 & 97,88 & 105,31 & 117,56 \\
\hline 1.1. Dochody bieżące & 169,35 & 168,27 & 170,17 & 173,84 & 171,72 & 176,07 & 200,73 & 101,40 & 104,63 & 117,96 \\
\hline podatek dochodowy od osób fizycznych & 34,54 & 35,38 & 36,66 & 37,74 & 35,10 & 38,10 & 41,11 & 101,63 & 107,70 & 112,13 \\
\hline podatek dochodowy od osób prawnych & 6,42 & 6,57 & 6,81 & 7,01 & 6,40 & 7,08 & 7,44 & 99,65 & 107,69 & 109,32 \\
\hline podatek od nieruchomości & 19,41 & 19,75 & 20,27 & 20,63 & 19,50 & 20,17 & 20,77 & 100,45 & 102,14 & 102,49 \\
\hline subwencja ogólna & 50,59 & 51,16 & 52,12 & 52,60 & 50,90 & 51,05 & 53,04 & 100,62 & 99,78 & 101,77 \\
\hline dotacje i środki na cele bieżące & 27,69 & 23,31 & 22,49 & 22,34 & 28,16 & 27,10 & 53,95 & 101,69 & 116,26 & 239,92 \\
\hline 1.2. Dochody majątkowe & 29,21 & 20,71 & 11,58 & 8,83 & 22,61 & 22,95 & 12,94 & 77,41 & 110,80 & 111,71 \\
\hline 2. WYDATKI OGÓŁEM & 212,74 & 187,44 & 177,11 & 176,77 & 196,75 & 196,40 & 206,03 & 92,49 & 104,78 & 116,33 \\
\hline 2.1. Wydatki bieżące & 160,11 & 153,17 & 154,26 & 156,23 & 155,61 & 157,85 & 180,20 & 97,19 & 103,06 & 116,82 \\
\hline wydatki na obsługę długu & 3,13 & 3,50 & 3,38 & 3,17 & 2,49 & 2,08 & 1,93 & 79,66 & 59,50 & 57,03 \\
\hline $\begin{array}{l}\text { wydatki bieżące na wynagrodzenia } \\
\text { i składki od nich naliczane }\end{array}$ & 68,52 & 67,89 & 68,73 & 69,04 & 69,30 & 71,44 & 62,09 & 101,13 & 105,23 & 90,34 \\
\hline 2.2. Wydatki majątkowe & 52,62 & 34,28 & 22,85 & 20,54 & 41,36 & 38,58 & 25,83 & 78,60 & 112,55 & 113,02 \\
\hline 3. WYNIK - DEFICYT/NADWYŻKA & $-14,18$ & 1,54 & 4,65 & 5,90 & $-2,41$ & 2,62 & 7,63 & - & - & - \\
\hline $\begin{array}{l}\text { 4. Różnica między dochodami bieżącymi } \\
\text { a wydatkami bieżącymi }\end{array}$ & 9,24 & 15,11 & 15,92 & 17,60 & 16,11 & 18,22 & 20,52 & 174,44 & 120,61 & 128,90 \\
\hline 5. Zadłużenie & 75,04 & 72,75 & 67,73 & 61,71 & 72,11 & 71,61 & 69,02 & 96,10 & 98,44 & 101,91 \\
\hline udział zadłużenia w dochodach ogółem & 37,80 & 38,50 & 37,26 & 33,80 & 37,11 & 35,98 & 32,30 & - & - & - \\
\hline
\end{tabular}

Źródło: opracowanie własne na podstawie danych MF. 
problemu, związanego z wiarygodnością danych zawartych w planach, jakie sporządzają JST, należy uznać za negatywne. Podobnie wygląda sytuacja dla kategorii wydatków majątkowych, a także niezwykle istotnej z punktu widzenia oceny kondycji finansowej JST kategorii nadwyżki operacyjnej. W przypadku tej ostatniej wskaźnik wykonanie - plan w latach 2014-2016 wynosił kolejno 174,44\%, 120,61\% oraz $128,9 \%$. Najwyższa trafność planu i wykonania daje się natomiast odnotować w takich kategoriach, jak: podatek od nieruchomości (wskaźnik średni za trzy lata 101,69\%), subwencja ogólna (wskaźnik średni za trzy lata 100,72\%), oraz zadłużenie (wskaźnik średni za trzy lata 98,82\%) (por. tabela 1).

$\mathrm{Na}$ temat słabej jakości planowania w samorządach w podobnym tonie wypowiedziała się Krajowa Rada RIO, wskazując w swoim raporcie za 2015 rok na zasadnicze rozbieżności pomiędzy kwotami WPF a wykonaniem lokalnych budżetów (por. [RIO przypomina...]). Jak pokazują badania, niektóre JST planują swoje WPF nawet w horyzoncie ponad 40 lat. Jeżeli WPF miałby spełniać - zgodnie z założeniami - funkcję zarządzania finansami, to jakość planowania, wpływająca na wiarygodność danych musi ulec znaczącej poprawie. Słabością WPF jako instrumentu zarządzania niewątpliwie jest też brak jednoznacznego określenie relacji pomiędzy WPF a budżetem rocznym w przepisach (por. art. 229 ufp $^{5}$ ).

\section{Powiązanie wieloletniego planowania finansowego $\mathrm{z}$ wieloletnim planem inwestycyjnym oraz budżetem rocznym}

Z punktu widzenia wzajemnych relacji pomiędzy rocznym i wieloletnim planowaniem warte podkreślenia jest wzajemne przenikanie się procesów planistycznych, wykorzystywanie tych samych danych na różnych etapach planistycznych oraz konieczność zachowania absolutnej rzetelności w planowaniu, zarówno w krótkim, jak i w długim okresie. Tę specyficzną korelację pomiędzy planowaniem rocznym a wieloletnim można opisać następująco. Budżet roczny jest wynikiem ustaleń wieloletnich zawartych w WPF oraz bieżących rocznych potrzeb JST. Równocześnie $\mathrm{w}$ wyniku ustaleń zawartych w budżecie rocznym powstaje np. w roku kolejnym potrzeba uaktualnienia WPF. Ta przynajmniej coroczna aktualizacja WPF wiąże się z ich urealnieniem, uwzględnieniem nowych okoliczności i uwarunkowań lokalnych. W rzeczywistości JST aktualizują swoje WPF nawet kilkanaście razy w roku, na ogół przy każdej zmianie uchwały budżetowej.

$\mathrm{Na}$ wzajemne powiązania pomiędzy wieloletnim planowaniem finansowym, wieloletnim planowaniem inwestycyjnym, budżetem rocznym oraz strategią rozwoju, również zarządzaniem długiem zwracali uwagę m.in.: Lewcock [1998], Pakoński

${ }^{5}$ Art. 229 mówi, iż wartości przyjęte w wieloletniej prognozie finansowej i budżecie jednostki samorządu terytorialnego powinny być zgodne co najmniej w zakresie wyniku budżetu i związanych z nim kwot przychodów i rozchodów oraz długu jednostki samorządu terytorialnego (Dz.U. z 2013, poz. $885 \mathrm{ze} \mathrm{zm}$.). 
(red.) [2000], Kavanagh [2007], Krajewska i Jońca [2012], Filipiak [2016]. Występujące pomiędzy nimi sprzężenia zwrotne, związana z nimi ocena rezultatów wynikających z realizacji zadań i programów mają służyć poprawie efektywności zarządzania JST, w tym zarządzania finansami. Połączenie jednorocznego budżetu i planu finansowego jest bezpośrednie i natychmiastowe. Ocena rezultatów i wskaźników finansowych dotyczy budżetu oraz WPF, zaś w wyniku ich analizy zmianie może ulec strategia, zarówno jej cele, jak i mierniki. Wieloletnie planowanie finansowe jest niezbędne przy wdrażaniu strategii rozwoju JST, uwzględnia priorytety strategii rozwoju gospodarczego, określając jednocześnie ramy finansowania zaplanowanych do realizacji zadań inwestycyjnych oraz świadczenia usług bieżących (por. rys. 2).

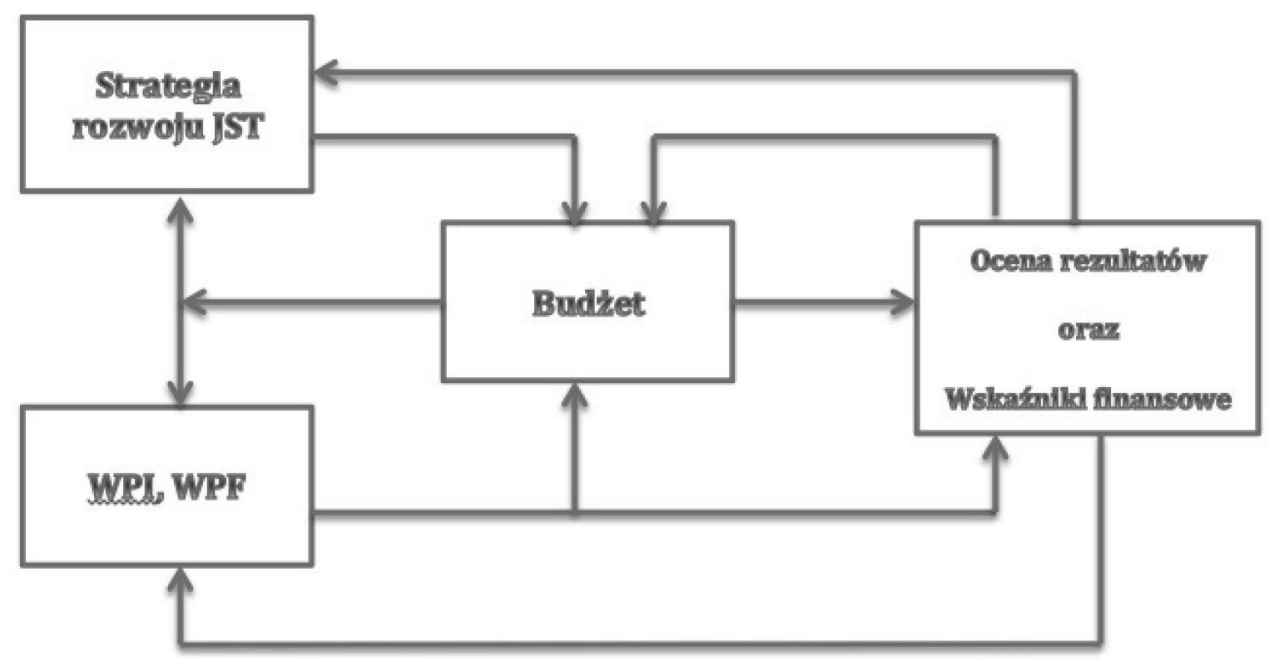

Rys. 2. Wzajemne powiązania planowania wieloletniego i budżetu

Źródło: opracowanie własne na podstawie [Kavanagh 2007, s. 8; Cichocki 2013, s. 41].

Wartości przyjęte w WPF oraz budżecie powinny być zgodne, podobnie wydatki inwestycyjne w obu dokumentach czy dane dotyczące wyniku budżetu i związanych z nim przychodów i rozchodów. Zmiana w budżecie powoduje zmiany w WPF i odwrotnie - weryfikacja WPF wymaga zmian w budżecie. Z kolei WPI jest podstawą przygotowania części inwestycyjnej budżetu rocznego w kolejnych latach. Wprowadzenie nowego zadania inwestycyjnego do budżetu powinno być też uwzględnione w WPI oraz WPF, a obydwa dokumenty zweryfikowane w całym przyszłym analizowanym okresie, nie tylko w roku, w którym dokonaliśmy zmiany. Unifikacja i aktualizacja danych jest bardzo ważna, musi się odbywać na bieżąco i tak należy rozumieć wzajemne powiązania, jakie występują pomiędzy dokumentami planowania wieloletniego i rocznego. 


\section{Wnioski}

Przeprowadzona w artykule analiza założeń metodologicznych sporządzania WPF, obowiązujących przepisów prawnych, dostępnych opracowań oraz obserwacja stosowanych przez JST praktyk pozwalają na postawienie następujących kilku zasadniczych wniosków.

Po pierwsze, WPF może być wykorzystywany jako narzędzie do efektywnego zarządzania finansami JST i tym samym lepszego wykorzystania środków publicznych. Wymaga to jednak od sporządzających WPF zachowania i przestrzegania wielu zasad, w szczególności odpowiedniego zorganizowania procesu planistycznego, w tym jego standaryzacji, a także dużej staranności przy planowaniu. WPF, aby mógł stanowić instrument strategicznego zarządzania, nie tylko musi być właściwie skonstruowany, ale też powinien odzwierciedlać analizę priorytetów wspólnoty samorządowej oraz misję samej JST.

W procesie konstruowania WPF ogromną rolę odgrywa umiejętność prognozowania. Prawidłowo przeprowadzona prognoza wymaga dogłębnej diagnozy i analizy poszczególnych dziedzin i kategorii prognozowania, m.in. dochodów i wydatków, przychodów i rozchodów, a także zadłużenia, kosztów obsługi długu czy wydatków inwestycyjnych. Prognozowanie to nie tylko umiejętność przewidywania trendów czy zmieniających się potrzeb społeczności lokalnej, lecz także umiejętność przyjęcia określonej polityki zarządzania JST oraz definiowania i kreowania jej polityk w określonych obszarach. Samo tylko wyznaczenie optymalnego poziomu zadłużenia w sposób odpowiedzialny i rzetelny jest niebagatelnym wyzwaniem, wziąwszy pod uwagę możliwe dzisiaj wyłączenia z kategorii długu.

Ponadto w całym procesie planowania WPF wymagane jest zapewnienia realności danych. Analiza planu i wykonania dla głównych kategorii w latach 2014-2016 wskazuje na silne odchylenia. To oznacza, że w dzisiejszym kształcie WPF nie wykorzystuje swoich funkcji zarządczych, lecz jest raczej wypełnieniem ustawowego obowiązku. Aby WPF mógł wypełniać rolę narzędzia zarządzania finansami, jakość planowania zdecydowanie musi się poprawić.

Na sytuację tę pozytywny wpływ może mieć nie tylko poprawa i udoskonalanie metodyki planowania, ale też m.in. nowelizacja niektórych zapisów ustawy o finansach publicznych, np. wymogu dotyczącego prognozy kwoty długu (art. 227, pkt 2) czy zapisów art. 229 ufp dotyczącego wzajemnych relacji pomiędzy budżetem rocznym a WPF. Rozważenie np. skrócenia czasu, na jaki ma być projektowany WPF, do maksymalnie 4 lat, również w części dotyczącej projektowania długu, czy też doprecyzowanie intencji przepisów art. 229 ufp, tak aby zachowując zgodność danych zawartych w WPF-ach oraz budżetach rocznych, nie zatracić w tym procesie zakładanego strategicznego i nadrzędnego charakteru WPF, może przyczynić się do bardziej skutecznego wykorzystania WPF jako narzędzia zarządzania finansami.

Warto też zwrócić uwagę na to, iż WPF jest jedną z wielu uzupełniających się metod w ramach zintegrowanego zarządzania JST i poza samym WPF obejmuje 
metodologię wieloletniego planowania inwestycji, budżetowanie zadaniowe, budowanie strategii JST oraz jej polityk sektorowych. Pomiędzy WPF a wymienionymi technikami występują pewne zależności, które należy rozpoznać i wykorzystać przy podejmowaniu decyzji. Dotyczy to w szczególności relacji pomiędzy WPF a planowaniem rocznym w układzie zadań, które cechuje wysoka precyzyjność, wiarygodność oraz obiektywizm przy podejmowaniu decyzji, co w sytuacji rosnących i usztywniających się kosztów bieżących zadań ma kluczowe znaczenie dla planowania nadwyżki operacyjnej.

Pomimo wielu słabości wynikających dzisiaj z ustawy czy praktyk stosowanych przez JST, WPF wypracowuje u pracowników samorządowych nawyk wieloletniego myślenia o finansowaniu zadań, rozwoju oraz ryzykach, jakie mogą wystąpić w związku z ich realizacją w przyszłości. Wieloletnie planowanie, nawet jeżeli nie jest zbyt dokładne, to jednak zwiększa świadomość decydentów co do możliwości wystąpienia zagrożeń w przyszłości oraz wskazuje na istnienie potencjalnych nowych szans, o których nie wiedzieliby, gdyby nie planowali w układzie wieloletnim.

WPF, poprawnie wykonana, wdrożona i wykorzystywana, może przyczynić się do podwyższenia efektywności zarządzania potencjałem JST.

\section{Literatura}

Cichocki K. 2001, Wieloletnie planowanie finansowe, Municipium, Warszawa.

Cichocki K., 2013, Zarzadzanie finansami i dlugiem samorzadu terytorialnego w perspektywie wieloletniej, IBSPAN, Warszawa.

Czekaj M., 2015, Sytuacja samorząów u progu nowego etapu finansowania 2014-2020 - wystęujące ograniczenia, Finanse Komunalne, nr 1-2.

Czekaj M., Kondraszewicz P., 2016, Wieloletnia prognoza finansowa - narzędzie administracyjne czy zarzadcze? Finanse Komunalne, $\mathrm{nr} 11$.

Dylewski M., 2007, Planowanie budzetowe w podsektorze samorzadowym. Uwarunkowania, procedury, modele, Difin, Warszawa.

Filas J., Piszczek M., 1999, ABC budżetu zadaniowego, Agencja Rozwoju Komunalnego - Fundacja Skarbu Państwa, Warszawa.

Filas J., Piszczek M., Stobnicka I., 1999, Budżet zadaniowy. Narzędzia i procedury, Agencja Rozwoju Komunalnego - Fundacja Skarbu Państwa, Warszawa.

Filipiak B., 2016, Instrumenty i narzędzia zarządzania dlugiem - ocena spójności z wieloletnia prognoza finansowa, Finanse Komunalne, nr 11.

Jastrzębska M., 2016, Nadmierne zadtużanie się jednostek samorządu terytorialnego - przyczyny, skutki, przeciwdziałanie, Finanse Komunalne, nr 6.

Kavanagh S.C., 2007, Financing the Future: Long-Term Financial Planning for Local Government, GFOA, Washington D.C.

Krajewska M., Jońca A., 2012, Wieloletnia prognoza finansowa jako instrument zarzadzania gospodarka finansowa JST - podsumowanie dwóch lat doświadczeń, Finanse Komunalne, nr 11.

Lewcock T., 1998, Handbook for Perforamnce Management, Sunnyvale, CA.

Nawrocki B., 2016, Model szacowania optymalnego poziomu zadlużenia oraz maksymalnych wydatków inwestycyjnych, Finanse Komunalne, nr 1-2. 
Piszczek M., 2016, Financial Planning in Local Governments Units - Selected Methodological Aspects, [w:] Buła P., Teczke J., Trifonova N.V. (eds.), Challenges for Contemporary Management, International Management Foundation, University of Economics, Cracow, s. 95-108.

Pakoński K. (red.), 2000, Budżet, Municipium, Warszawa.

Rio przypomina. Czas na lokalne budżety oraz wieloletnie prognozy finansowe, http://samorzad.pap.pl/ depesze/temat_dnia/169581/RIO-przypomina-czas-na-lokalne-budzety (1.12.2016).

Rozporządzenie Ministra Finansów z dnia 10 stycznia 2013 r. w sprawie wieloletniej prognozy finansowej jednostki samorządu terytorialnego, Dz.U. z 2013, poz. 86.

Salachna J., 2015, Dlaczego należy poprawić mechanizmy wieloletniej prognozy finansowej?, Finanse Komunalne, nr 1-2.

Salachna J., 2016, Czy prawna regulacja w zakresie wieloletniej prognozy finansowej ma sens?, Finanse Komunalne, $\mathrm{nr} 11$.

Surówka K., 2016, Pozyskiwanie środków unijnych a problem zadlużania się jednostek samorzadu terytorialnego w okresie 2007-2013 - wnioski dla władz samorzadowych w nowej perspektywie, Finanse Komunalne, $\mathrm{nr} 9$.

Szewczuk J., 2016, Przed jakimi wyzwaniami stoja samorządy i dlaczego musza wspótpracować, [w:] Potkański T. (red.), Wspótpraca jednostek samorządu terytorialnego narzędziem wsparcia polityki rozwoju, ZMP, Poznań.

Tarnowski W., 2015, Wieloletnia prognoza finansowa - fikcja czy instrument stabilizacji finansowej samorzadu? Polemika, Finanse Komunalne, nr 5.

Ustawa z dn. 27.08.2009 r. o finansach publicznych, Dz.U. z 2013, poz. 885 ze zm.

Woźniak D., 2015, Wieloletnie planowanie na podstawie wieloletnich prognoz finansowych, Finanse Komunalne, nr 1-2.

www.mf.gov.pl

Wyszkowska D., Wyszkowski A., 2016, Dylematy wieloletniej prognozy finansowej w jednostkach samorzadu terytorialnego w ujęciu teoretycznym, Finanse Komunalne, nr 11. 